\title{
Inhibition of telomerase activity in renal cell carcinoma cells by doxorubicin and anti-Fas monoclonal antibody
}

\author{
XINGHUA JIN $^{1^{*}}$, YIFEI LI ${ }^{2 *}$, YONGNAN LI ${ }^{3}$, CHENGLUO JIN ${ }^{2}$, JIFEI ZHANG ${ }^{1}$ and JICHENG LIU $^{1}$ \\ ${ }^{1}$ Institute of Medicine, Qiqihar Medical University, Qiqihar; ${ }^{2}$ Department of Urology, Second Affiliated Hospital, \\ Harbin Medical University, Harbin; ${ }^{3}$ Department of Preventive Medicine, \\ Mudanjiang Medical University, Mudanjiang, P.R. China
}

Received January 16, 2009; Accepted May 14, 2009

DOI: 10.3892/mmr_00000156

\begin{abstract}
Telomerase, the ribonucleoprotein enzyme that maintains the telomeres of eukaryotic chromosomes, is an attractive target for a mechanism-based therapeutic approach as its activation has been associated with unlimited proliferation in most types of cancer cells. Here, we investigated the effect of chemotherapeutic or immunotherapeutic agents and anti-Fas monoclonal antibody (mAb) on telomerase activity in renal cell carcinoma (RCC) cells. Primary RCC cells were surgically obtained from 24 patients with RCC. Telomerase activity and cytotoxicity were determined by the telomeric repeat amplification protocol and 3-(4,5-dimethylthiazol2-yl)-2,5-diphenyltetrazolium bromide assay, respectively. Telomerase activity was positive in 20 (83.3\%) of the 24 primary RCC cell cultures. Treatment of ACHN human RCC cells with anti-Fas $\mathrm{mAb}$ in combination with vinblastine, interferon- $\alpha$ or interferon- $\gamma$ did not affect telomerase activity. However, a combination of anti-Fas $\mathrm{mAb}$ and doxorubicin resulted in marked down-regulation of telomerase activity in conjunction with a synergistic cytotoxicity. This inhibitory effect on telomerase activity was also observed in 16 telomerase-positive primary RCC cell cultures. These findings suggest that telomerase may be a promising molecular target for combination therapy using biological response modifiers and doxorubicin for RCC.
\end{abstract}

Correspondence to: Dr Xinghua Jin, Institute of Medicine, Qiqihar Medical University, 333 Bukui Street, Qiqihar, Heilongjiang 161042, P.R. China

E-mail: xin_ghuajin@yahoo.cn

Dr Yongnan Li, Department of Preventive Medicine, Mudanjiang Medical University, Aiminqu-Tongxiangjie 3, Mudanjiang 157011, P.R. China

E-mail: yongnanli@gmail.com

${ }^{*}$ Contributed equally

Key words: telomerase activity, renal cell carcinoma, doxorubicin, anti-Fas monoclonal antibody, cytotoxicity

\section{Introduction}

Renal cell carcinoma (RCC) is the tenth leading cause of cancer-related mortality in Western countries. It is resistant to conventional cancer treatments, and the incidence of distant metastases is high $(1,2)$. Although several molecular-targeted agents to curb RCC growth are currently being used with some success, no effective systemic therapy presently exists for patients with metastatic RCC, and new treatment strategies are urgently needed $(3,4)$. In previous studies, treatment with chemotherapeutic agents in combination with biological response modifiers, including anti-Fas monoclonal antibody $(\mathrm{mAb})$ and tumor necrosis factor-related apoptosis-inducing ligand (TRAIL), resulted in a significant potentiation of cytotoxicity and synergy in a variety of RCC cells $(5,6)$.

The synergistic cytotoxicity of anti-Fas $\mathrm{mAb}$ and doxorubicin (DOX) has been associated with the augmentation of Fas and p53 expression, the activation of caspase- 3 and the accumulation of intercellular DOX $(5,7)$. However, the precise mechanism of this synergistic cytotoxicity has yet to be clarified.

Telomerase, the ribonucleoprotein enzyme which maintains the telomeres of eukaryotic chromosomes, is an attractive target for a mechanism-based therapeutic approach since its activation has been associated with unlimited proliferation in most types of cancer cells (8-11). While the primary function of telomerase is the maintenance of structural integrity at the linear chromosome ends, recent studies have shown an association between telomerase activity and increased chemotherapeutic resistance consistent with poor prognosis in various types of cancer (12-14). Telomerase appears to mediate its protective effect by conferring resistance to apoptosis $(15,16)$. Therefore, inhibition of telomerase might represent a novel therapeutic strategy for the treatment of cancer.

In this study, we investigated telomerase activity in 3 human RCC cell lines and in primary RCC cells derived from 24 patients. We further examined the effect of anti-Fas mAb and chemotherapeutic or immunotherapeutic agents on telomerase activity in the RCC cells.

\section{Materials and methods}

Reagents. Anti-Fas mAb (CH-11) and DOX were purchased from Medical \& Biological Laboratories (Nagoya, Japan) and Sigma (St. Louis, MO), respectively. 
Table I. Clinicopathological variables and telomerase activity in primary RCC cells. ${ }^{\mathrm{a}}$

\begin{tabular}{|c|c|c|c|c|c|}
\hline \multirow[b]{2}{*}{ Patient no. } & \multicolumn{4}{|c|}{ Clinicopathologic variables } & \multirow[b]{2}{*}{ Telomerase activity } \\
\hline & Age/Gender & Stage & Grade & Cell type & \\
\hline 1 & $68 / \mathrm{F}$ & T3bN1M0 & 2 & Clear & + \\
\hline 2 & $70 / \mathrm{M}$ & T2N0M0 & 2 & Clear & + \\
\hline 3 & $70 / \mathrm{M}$ & T2N0M0 & 1 & Clear & + \\
\hline 4 & $76 / F$ & T3bN0M1 & 2 & Clear & + \\
\hline 5 & $63 / \mathrm{M}$ & T2NOM0 & 1 & Clear & + \\
\hline 6 & $77 / \mathrm{F}$ & $\mathrm{T} 2 \mathrm{~N} 4 \mathrm{M} 0$ & 2 & Clear & + \\
\hline 7 & $56 / \mathrm{F}$ & T1N0M0 & 2 & Chromophobe cell carcinoma & + \\
\hline 8 & $55 / \mathrm{M}$ & T1N0M0 & 2 & Granular & + \\
\hline 9 & $45 / \mathrm{M}$ & T2NOM0 & 2 & Clear & + \\
\hline 10 & $69 / \mathrm{M}$ & T1N0M0 & 2 & Clear & + \\
\hline 11 & $62 / \mathrm{M}$ & T2N0M0 & 1 & Clear & + \\
\hline 12 & $64 / F$ & T2NOM0 & 2 & Clear & + \\
\hline 13 & $73 / \mathrm{F}$ & T2N0M0 & 2 & Clear & + \\
\hline 14 & $63 / \mathrm{M}$ & T3bN2M1 & 2 & Clear & + \\
\hline 15 & $66 / \mathrm{M}$ & T2N0M0 & 2 & Clear & + \\
\hline 16 & $67 / \mathrm{F}$ & T2N0M0 & 2 & Granular & + \\
\hline 17 & 64/M & T2N0M0 & 2 & Clear & + \\
\hline 18 & $67 / F$ & T2NOMO & 2 & Clear & + \\
\hline 19 & $70 / \mathrm{F}$ & T3aNOM0 & 2 & Granular & + \\
\hline 20 & $37 / \mathrm{M}$ & T2N0M0 & 1 & Clear & + \\
\hline 21 & $60 / \mathrm{M}$ & T2N0M0 & 2 & Clear & - \\
\hline 22 & $55 / \mathrm{M}$ & T2N0M0 & 1 & Clear & - \\
\hline 23 & $58 / \mathrm{M}$ & T3aN0M1 & 3 & Clear & - \\
\hline 24 & $76 / \mathrm{F}$ & T2NOM0 & 1 & Clear & - \\
\hline
\end{tabular}

aTelomerase activity in primary RCC cells derived from 24 patients was determined using the TRAP assay. +, positive telomerase activity; -, negative telomerase activity.

Human RCC cell lines and primary RCC cells. The human RCC cell lines ACHN, A704 and NC65 were purchased from the American Type Culture Collection (Rockville, MD). Cells were cultured in RPMI-1640 supplemented with $25 \mathrm{mM} \mathrm{HEPES,}$ $100 \mathrm{U} / \mathrm{ml}$ penicillin, $100 \mu \mathrm{g} / \mathrm{ml}$ streptomycin and $10 \%$ fetal bovine serum at $37^{\circ} \mathrm{C}$ in a humidified $5 \% \mathrm{CO}_{2}$ atmosphere.

Primary RCC cells were separated from the surgical specimens of 24 untreated RCC patients as previously described (5). Pathological grades and stages were, respectively, G1 $(n=6)$, G2 (n=17), G3 (n=1), T1 (n=3), T2 (n=16), T3 (n=16), N1 $(n=1), N 2(n=1)$ and M1 $(n=3)$. The clinicopathological characteristics of the patients enrolled in this study are summarized in Table I. The study was conducted in accordance with the ethical principles of the Declaration of Helsinki. Written informed consent was obtained from all patients.

Assessment of telomerase activity. Telomerase activity was assessed by the conventional telomeric repeat amplification protocol (TRAP) assay as described elsewhere, with some modifications (17). RCC cells were homogenized in $100 \mu \mathrm{l}$ icecold lysis reagent, incubated for $30 \mathrm{~min}$ on ice and centrifuged at $15000 \mathrm{rpm}$ for $20 \mathrm{~min}$ at $4^{\circ} \mathrm{C}$. After centrifugation, the supernatant was recovered, snap-frozen in liquid nitrogen and stored at $-80^{\circ} \mathrm{C}$ until use. The protein concentration of the lysate was determined using the Bio-Rad DC protein assay (Bio-Rad, CA). Cell extract ( $3 \mu \mathrm{l}$ ) corresponding to $1 \mu \mathrm{g}$ total protein was incubated with $25 \mu \mathrm{l}$ reaction mixture and $22 \mu \mathrm{l}$ sterilized water for $30 \mathrm{~min}$ at $25^{\circ} \mathrm{C}$, and subsequently heated at $95^{\circ} \mathrm{C}$ for $5 \mathrm{~min}$ in the thermocycler block. The PCR conditions were $30 \mathrm{sec}$ at $94^{\circ} \mathrm{C}, 30 \mathrm{sec}$ at $50^{\circ} \mathrm{C}$ and $90 \mathrm{sec}$ at $72^{\circ} \mathrm{C}$ for 30 cycles. The amplified products were separated in $10 \%$ non-denatured acrylamide gels, then transferred onto a nylon membrane (Hybond-N+: Amersham, Bucks, UK) overnight by semi-dry transfer methods. Signal detection was carried out by chemiluminescence using an Imaging High Chemifluorescence Detection kit (Toyobo, Osaka, Japan) (18).

Telomerase activity was considered positive when a 6-baseladder extension was detected. The experiment was peformed in triplicate to validate the results. For confirmation that the TRAP signal was derived from telomerase activity, the telomerasepositive lysates were pre-treated with ribonuclease (RNase). This demonstrated that the signals were sensitive to RNase.

Cytotoxicity assay. Cytotoxicity was assessed by the 3-(4,5dimethylthiazol-2-yl)-2,5-diphenyltetrazolium bromide(MTT) assay as previously described (6). Briefly, a 100- $\mu$ l suspension 


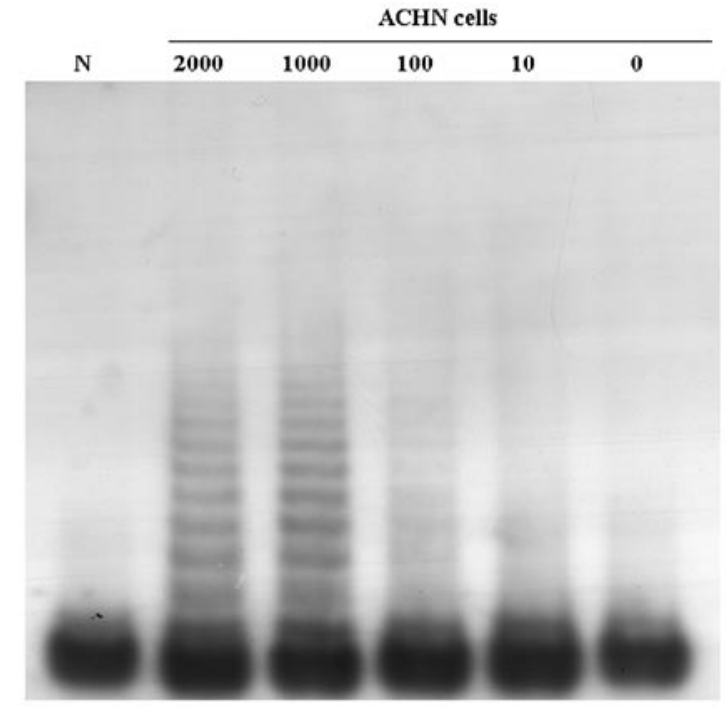

Figure 1. Telomerase activity was detected in $>10$ cancer cells per sample in ACHN cells using the TRAP assay. Lane N, negative control.

of $1 \times 10^{4}$ cells was seeded into a 96-well flat-bottom microtiter plate. After incubation for $24 \mathrm{~h}, 100 \mu \mathrm{l}$ of the drug solution or medium (control) was added to the plates, and each plate was incubated for an additional $24 \mathrm{~h}$. This was followed by the addition of $20 \mu \mathrm{l}$ MTT working solution ( $5 \mathrm{mg} / \mathrm{ml}$, Sigma) for $4 \mathrm{~h}$, then $100 \mu \mathrm{l}$ of isopropanol supplemented with $0.05 \mathrm{~N}$ hydrochloric acid for $30 \mathrm{~min}$. Absorbance (A) was measured using a microplate reader (Bio-Rad, Tokyo, Japan) at $570 \mathrm{~nm}$ with a 630-nm reference. Percent cytotoxicity $=1$ - (A of experimental wells/A of control wells) x 100].

Statistical analysis. Experiments were conducted in triplicate, and the results were expressed as the means \pm SD. Statistical significance was determined by the Student's t-test. $\mathrm{P}<0.05$ was considered significant.

\section{Results}

Telomerase activity in primary RCC cells. To evaluate the sensitivity of the TRAP assay for telomerase, we initially determined telomerase activity in lysate extracted from 10-2000 human ACHN RCC cells. Telomerase activity was detected in $>10$ of the extracts from ACHN cells, but was not detected in the extracts pre-treated with RNase (Fig. 1).

Next, telomerase activity in primary RCC cells derived from 24 patients was examined using the TRAP assay. Telomerase was positive in $20(83.3 \%)$ of the 24 primary RCC cell cultures (Table I). The levels of telomerase activity in the RCC cells, shown in Table I, were consistent with previously reported results $(19,20)$. Telomerase activity in RCC cells was not associated with clinical or pathological variables, such as clinical stage, grade or pathological subtype.

Suppression of telomerase activity and cytotoxicity in RCC cells by DOX and anti-Fas $m A$ b. We examined whether telomerase activity could be down-regulated by a combination treatment with anti-Fas $\mathrm{mAb}$ and chemotherapeutic or immunotherapeutic agents in RCC cells. Anti-Fas mAb (1-100 ng/ml)

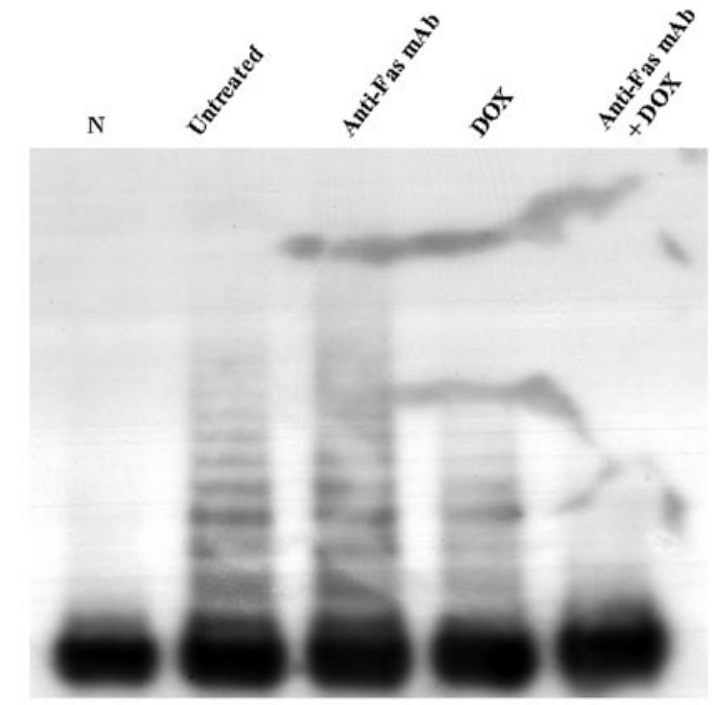

Figure 2. Telomerase activity in ACHN cells treated with anti-Fas mAb and doxorubicin (DOX). ACHN cells were treated for $24 \mathrm{~h}$ with $100 \mathrm{ng} / \mathrm{ml}$ anti-Fas $\mathrm{mAb}, 10 \mu \mathrm{g} / \mathrm{ml} \mathrm{DOX}$ alone, or a combination of these agents. Telomerase activity was detected using the TRAP assay. Lane N, negative control.

Table II. Telomerase inhibition correlated with cytotoxicity in ACHN cells treated with anti-Fas mAb in combination with doxorubicin. ${ }^{\mathrm{a}}$

\begin{tabular}{lcc}
\hline Treatment & $\begin{array}{c}\text { Telomerase } \\
\text { activity }\end{array}$ & $\begin{array}{c}\% \text { Cytotoxicity } \\
\text { (mean } \pm \text { SD) }\end{array}$ \\
\hline Untreated & + & 0 \\
Anti-Fas mAb & + & $12.7 \pm 2.1$ \\
DOX & + & $26.6 \pm 5.9$ \\
DOX + anti-Fas mAb & - & $81.7 \pm 6.0^{\mathrm{b}}$ \\
VLB & + & $12.7 \pm 2.2$ \\
VLB + anti-Fas mAb & + & $25.7 \pm 3.4$ \\
INF- $\alpha$ & + & $11.0 \pm 2.0$ \\
INF- $\alpha+$ anti-Fas mAb & + & $22.0 \pm 5.3$ \\
INF- $\gamma$ & + & $12.4 \pm 3.9$ \\
INF- $\gamma+$ anti-Fas mAb & + & $23.7 \pm 4.8$
\end{tabular}

${ }^{a}$ ACHN cells were treated for $24 \mathrm{~h}$ with $10 \mu \mathrm{g} / \mathrm{ml}$ doxorubicin (DOX), $10 \mu \mathrm{g} / \mathrm{ml}$ vinblatine (VBL), $1000 \mathrm{ng} / \mathrm{ml}$ interferon (IFN)- $\alpha$, $1000 \mathrm{ng} / \mathrm{ml}$ IFN- $\gamma, 100 \mathrm{ng} / \mathrm{ml}$ anti-Fas mAb alone, or a combination of these agents. Telomerase activity and cytotoxicity were assessed by the TRAP and MTT assays, respectively. + , positive telomerase

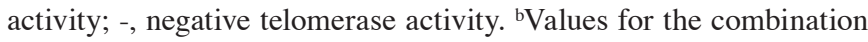
were significantly higher than those achieved by treatment with each agent alone $(\mathrm{P}<0.001)$.

did not have an inhibitory effect in combination with vinblatine (VBL; $0.1-10 \mu \mathrm{g} / \mathrm{ml})$, interferon- $\alpha$ (IFN- $\alpha$; 10-1000 $\mathrm{ng} / \mathrm{ml})$ or interferon- $\gamma$ (IFN- $\gamma ; 10-1000 \mathrm{ng} / \mathrm{ml})$. However, telomerase activity was markedly decreased and even disappeared when $\mathrm{ACHN}$ cells were treated with a combination of anti-Fas $\mathrm{mAb}$ (1-100 $\mathrm{ng} / \mathrm{ml})$ and DOX (1-10 $\mu \mathrm{g} / \mathrm{ml})$ for $24 \mathrm{~h}$, although each agent alone had no effect (Fig. 2; Table II). The inhibition of telomerase activity was also observed when ACHN cells were 
Table III. Telomerase activity in primary RCC cells treated with anti-Fas $\mathrm{mAb}$ and doxorubicin. ${ }^{\mathrm{a}}$

\begin{tabular}{|c|c|c|c|c|}
\hline \multirow[b]{2}{*}{$\begin{array}{l}\text { Patient } \\
\text { no. }\end{array}$} & \multicolumn{4}{|c|}{ Telomerase activity } \\
\hline & Untreated & DOX & $\begin{array}{c}\text { Anti-Fas } \\
\text { mAb }\end{array}$ & $\begin{array}{c}\mathrm{DOX}+ \\
\text { anti-Fas mAb }\end{array}$ \\
\hline 1 & + & + & + & - \\
\hline 2 & + & + & + & - \\
\hline 3 & + & + & + & - \\
\hline 4 & + & + & + & - \\
\hline 5 & + & + & + & - \\
\hline 6 & + & + & + & - \\
\hline 7 & + & + & + & - \\
\hline 8 & + & + & + & - \\
\hline 9 & + & + & + & - \\
\hline 10 & + & + & + & - \\
\hline 11 & + & + & + & - \\
\hline 12 & + & + & + & - \\
\hline 13 & + & + & + & - \\
\hline 14 & + & + & + & - \\
\hline 15 & + & + & + & - \\
\hline 16 & + & + & + & - \\
\hline
\end{tabular}

aPrimary RCC cells derived from 16 patients were treated for $24 \mathrm{~h}$ with $10 \mu \mathrm{g} / \mathrm{ml}$ doxorubicin (DOX), $100 \mathrm{ng} / \mathrm{ml}$ anti-Fas mAb alone, or a combination of these agents. Telomerase activity was assessed using the TRAP assay. +, positive telomerase activity; -, negative telomerase activity.

treated with anti-Fas mAb in combination with DOX derivative epirubicin (data not shown). Furthermore, this inhibitory effect was not selective for the ACHN cell line; a similar effect was also achieved in two other RCC cell lines, A704 and NC65 (data not shown).

When ACHN cells were treated with a combination of anti-Fas $\mathrm{mAb}$ and DOX for $24 \mathrm{~h}$, significant potentiation of cytotoxicity and synergy was achieved (Table II; $\mathrm{P}<0.0001$ ). In contrast, there was no synergistic effect of anti-Fas $\mathrm{mAb}$ in combination with VBL, IFN- $\alpha$ or IFN- $\gamma$.

To determine whether the inhibitory effect was a reflection of the properties of the established cancer cell lines, we tested for telomerase in 16 telomerase-positive primary RCC cell cultures. In all cases, marked suppression of telomerase activity was observed (Table III).

\section{Discussion}

Telomerase is an attractive target for a mechanism-based therapeutic approach since its activation has been associated with sensitivity to chemotherapeutic agents in most types of cancer cells (12-16). However, little is known regarding the effect of biological response modifiers and chemotherapeutic agents on telomerase activity. In this study, we examined the effect of anti-Fas mAb and DOX on telomerase activity, not only in established human RCC cell lines, but also in primary RCC cells. We found that: a) telomerase was positive in $20(83.3 \%)$ of the 24 primary RCC cell cultures derived from patients; b) telomerase activity was markedly down-regulated by anti-Fas $\mathrm{mAb}$ and DOX in 3 human RCC cell lines and in 16 primary RCC cell cultures; and c) the inhibitory effect on telomerase in RCC cells was observed in conjunction with cytotoxic activity induced by anti-Fas mAb and DOX. These findings suggest that the suppression of telomerase is one of the mechanisms responsible for the synergistic cytotoxicity of anti-Fas $\mathrm{mAb}$ and DOX in RCC cells, and that telomerase may be a promising novel molecular target for combination therapy using biological response modifiers and chemotherapeutic agents for RCC.

In the present study, $83.3 \%$ of the primary RCC cell cultures were telomerase-positive. The frequency of telomerase activity in the primary RCC cells was consistent with previous studies using RCC tissues (19-21). Furthermore, there was no correlation between telomerase activity and clinicopathological variables. This was also consistent with previous studies. These results indicate that telomerase activity may not be a suitable prognostic indicator for RCC.

Several studies have shown that the sensitization of tumor cells to Fas-mediated apoptosis by chemotherapeutic agents is associated with initiator caspase- 8 activation and the cleavage of effector caspase-3, as well as the prototype caspase substrate poly(ADP-ribose) polymerase (22-24). Wu et al demonstrated that combination treatment with anti-Fas $\mathrm{mAb}$ and DOX significantly activated caspase-3 and induced synergistic apoptosis in RCC cells (5). It was also reported that treatment of malignant glioma cells with an antisense to human telomerase RNA component reduced telomerase activity and enhanced the apoptosis induced by the chemotherapeutic agent in vitro and in vivo (25). In the present study, we found that a combination of anti-Fas $\mathrm{mAb}$ and DOX resulted in marked down-regulation of telomerase activity, in conjunction with synergistic cytotoxicity in RCC cells. These results indicate that the inhibition of telomerase activity by anti-Fas $\mathrm{mAb}$ and DOX is associated with synergistic cytotoxicity and apoptosis. This link between telomerase inhibition and the enhancement of Fas-mediated apoptosis by DOX may provide a basis for future studies employing a combination of biological response modifiers and chemotherapeutic strategies for cancer treatment.

In conclusion, the present study demonstrated that a combination of anti-Fas mAb and DOX had an inhibitory effect on telomerase activity in all telomerase-positive RCC cells, and that the inhibition of telomerase activity may be associated with the synergistic cytotoxicity of anti-Fas mAb and DOX. These findings suggest that telomerase may be a promising novel molecular target for combination therapy using biological response modifiers and chemotherapeutic agents for RCC, although additional studies are warranted to elucidate the mechanisms involved in the inhibition of telomerase activity by these drugs.

\section{Acknowledgements}

The authors would like to thank Dr Xiuxian Wu of the Department of Urology, Faculty of Medicine, Kagawa University, for his comments and help with the preparation of the manuscript. 


\section{References}

1. Lilleby W and Fossa SD: Chemotherapy in metastatic renal cell cancer. World J Urol 23: 175-179, 2005.

2. Jemal A, Siegel R, Ward E, Murray T, Xu J and Thun MJ: Cancer statistics. CA Cancer J Clin 57: 43-66, 2007.

3. Vogelzang NJ: Treatment options in metastatic renal carcinoma: an embarrassment of riches. J Clin Oncol 24: 1-3, 2006.

4. Schrader AJ and Hofmann R: Metastatic renal cell carcinoma: recent advances and current therapeutic options. Anticancer Drugs 19: 235-245, 2008.

5. Wu XX, Mizutani Y, Kakehi Y, Yoshida O and Ogawa O: Enhancement of Fas-mediated apoptosis in renal cell carcinoma cells by adriamycin. Cancer Res 60: 2912-2918, 2000.

6. Wu XX, Kakehi Y, Mizutani Y, et al: Enhancement of TRAIL/ Apo2L-mediated apoptosis by adriamycin through inducing DR4 and DR5 in renal cell carcinoma cells. Int J Cancer 104: 409-417, 2003.

7. Wu X, Kakehi Y, Mizutani Y, Terachi T and Ogawa O: Increased intracellular doxorubicin by anti-FAS monoclonal antibody: a mechanism that enhances the cytotoxicity in renal cell carcinoma cells. Urology 57: 993-998, 2001.

8. Morin GB: The human telomere terminal transferase enzyme is a ribonucleoprotein that synthesizes TTAGGG repeats. Cell 59: 521-529, 1989

9. Blackburn EH: Structure and function of telomeres. Nature 350: 569-573, 1991.

10. Kim NW, Piatyszek MA, Prowse KR, et al: Specific association of human telomerase activity with immortal cells and cancer. Science 266: 2011-2015, 1994

11. Piatyszek MA, Kim NM, Weinrich SL, et al: Detection of telomerase activity in human cells and tumors by a telomeric repeat amplication protocol (TRAP). Methods Cell Sci 17: 1-15, 1995.

12. Kiyozuka Y, Yamamoto D, Yang J, et al: Correlation of chemosensitivity to anticancer drugs and telomere length, telomerase activity and telomerase RNA expression in human ovarian cancer cells. Anticancer Res 20: 203-212, 2000.

13. Yamada O, Kawauchi K, Akiyama M, et al: Leukemic cells with increased telomerase activity exhibit resistance to imatinib. Leuk Lymphoma 49: 1168-1177, 2008.

14. Eskiocak U, Ișeri OD, Kars MD, Biçer A and Gunduz U: Effect of doxorubicin on telomerase activity and apoptotic gene expression in doxorubicin-resistant and -sensitive MCF-7 cells: an experimental study. Chemotherapy 54: 209-216, 2008.
15. Kondo Y, Kondo S, Tanaka Y, Haqqi T, Barna BP and Cowell JK: Inhibition of telomerase increases the susceptibility of human malignant glioblastoma cells to cisplatin-induced apoptosis. Oncogene 16: 2243-2248, 1998.

16. Bermudez Y, Erasso D, Johnson N, Alfonso-De Matte M, Lowell $\mathrm{N}$ and Kruk P: Telomerase confers resistance to caspase-mediated apoptosis. Clin Intervent Aging 1: 155-167, 2006.

17. Akao T, Kakehi Y, Wu X-X, et al: Semi-quantitative analysis of telomerase activity of exfoliated cells in urine of patients with urothelial cancer: Causative factors affecting sensitivity and specificity. Urol Oncol 3: 118-124, 1997.

18. Beck S, O'Keeffe T, Coull JM and Koster H: Chemilumi-nescent detection of DNA: application for DNA sequencing and hybridization. Nucleic Acids Res 17: 5115-5122, 1989.

19. Mehle C, Piatyszek MA, Ljungberg B, Shay JW and Roos G: Telomerase activity in human renal cell carcinoma. Oncogene 13: 161-166, 1996.

20. Kinoshita H, Ogawa O, Mitsumori K, Kakehi Y, Terachi T and Yoshida O: Low frequency of positive telomerase activity in a chromophobe subtype of renal cell carcinoma. J Urol 159: 245-251, 1998.

21. Sugimura K, Yoshida N, Hisatomi H, Nakatani T and Ikemoto S: Telomerase activity in human renal cell carcinoma. BJU Int 83: 693-697, 1999.

22. Keane MM, Ettenberg SA, Nau MM, Russell EK and Lipkowitz S: Chemotherapy augments TRAIL-induced apoptosis in breast cell lines. Cancer Res 59: 734-741, 1999.

23. Micheau O, Hammann A, Solary E and Dimanche-Boitrel MT: STAT-1-independent upregulation of FADD and procaspase-3 and -8 in cancer cells treated with cytotoxic drugs. Biochem Biophys Res Commun 256: 603-607, 1999.

24. Fulda S, Strauss G, Meyer E and Debatin KM: Functional CD95 ligand and CD95 death-inducing signaling complex in activationinduced cell death and doxorubicin-induced apoptosis in leukemic T cells. Blood 95: 301-308, 2000.

25. Iwado E, Daido S, Kondo Y and Kondo S: Combined effect of 2-5A-linked antisense against telomerase RNA and conventional therapies on human malignant glioma cells in vitro and in vivo. Int J Oncol 31: 1087-1095, 2007. 